\title{
Housing Prices in Unregulated Markets: Study On Verticalised Dwellings in Santiago De Chile
}

\author{
Francisco Vergara-Perucich, Ph. D. Director Centro Producción del Espacio Universidad \\ de Las Américas. jvergara@udla.cl \\ Carlos Aguirre-Núñez, Ph. D. Director Escuela de Construcción, Universidad de Las \\ Américas. caguirre@udla.cl
}

\begin{abstract}
Chile faces a serious crisis on housing affordability given that most of the population is unable to secure a house. While housing prices between 2008 increased by $70.96 \%$, wages only increased by $20.43 \%$. This article presents the analysis of the housing prices configuration for the main district in the country: Santiago Centro. The assessment focuses on verticalised housing buildings constructed between 2015 and 2019. The article develops an exploratory study on the price of housing in the city of Santiago de Chile, to generate a diagnosis to identify the role played by expectations of profitability when configuring that price. Based on the information generated, we seek to contribute to the discussion on public policies that advance towards the development of affordable housing for households in central communes with high urban value, as is the case of Santiago Centro. We hypothesize that profitability expectations of real estate developers play a key role in the housing prices and an adjustment in the profit ratios may increase the affordability keeping the housing market over profitable rates. The research is relevant due to the lack of data transparency in the Chilean housing market, where access to investment costs, land values, yields and house price formation are not part of the public discussion, even though this implies that many households are facing severe difficulties in paying for access to decent housing.
\end{abstract}

Keywords: housing; Santiago de Chile; internal rate of return; net present value; affordability; profitability index

\section{Introduction}

In Chile, housing is a good subject in a low-regulation market, organised by market agents and subsidised by the state for lower-income households (Garreton, 2017a). Despite public policy efforts, there is strong evidence that demand-side subsidy for low-income housing projects has ended up increasing the price by contributing to their inflation (Razmilic, 2010). This also occurs for urban renewal subsidies, originally intended for the middle class, where the subsidy is captured by the company that sells the housing units, without directly benefiting buyers (López-Morales, 2016). On the other hand, the high value of the price of housing has been explained by actors in the Chilean real estate sector to be a consequence of the high value of land and its own scarcity (Hurtado, 2019). On the other hand, the shortage of land has been attributed by various experts, indicating that, in the city of Santiago, where the price of housing has risen the most, 555 hectares of land located in the urban pericenter of the city are still available to exploit (Trivelli, 2017), with what would exceed the structural demand of 497,560 housing units, very similar to the 1998 deficit quantified at 497,012 units (Housing Foundation, 2019). All this in spite of the fact that from 1998 to December 2018, 2,805,069 new housing units have been built (National Statistics Institute, 2019). Since 2008, the Real Housing Price Index has risen by $70.96 \%$ while workers' wages have only increased by $20.43 \%$ (Figure 1 ). 
Figure 1. Real housing price index in Chile versus global compensation index. Source: Central Bank of Chile (2018).

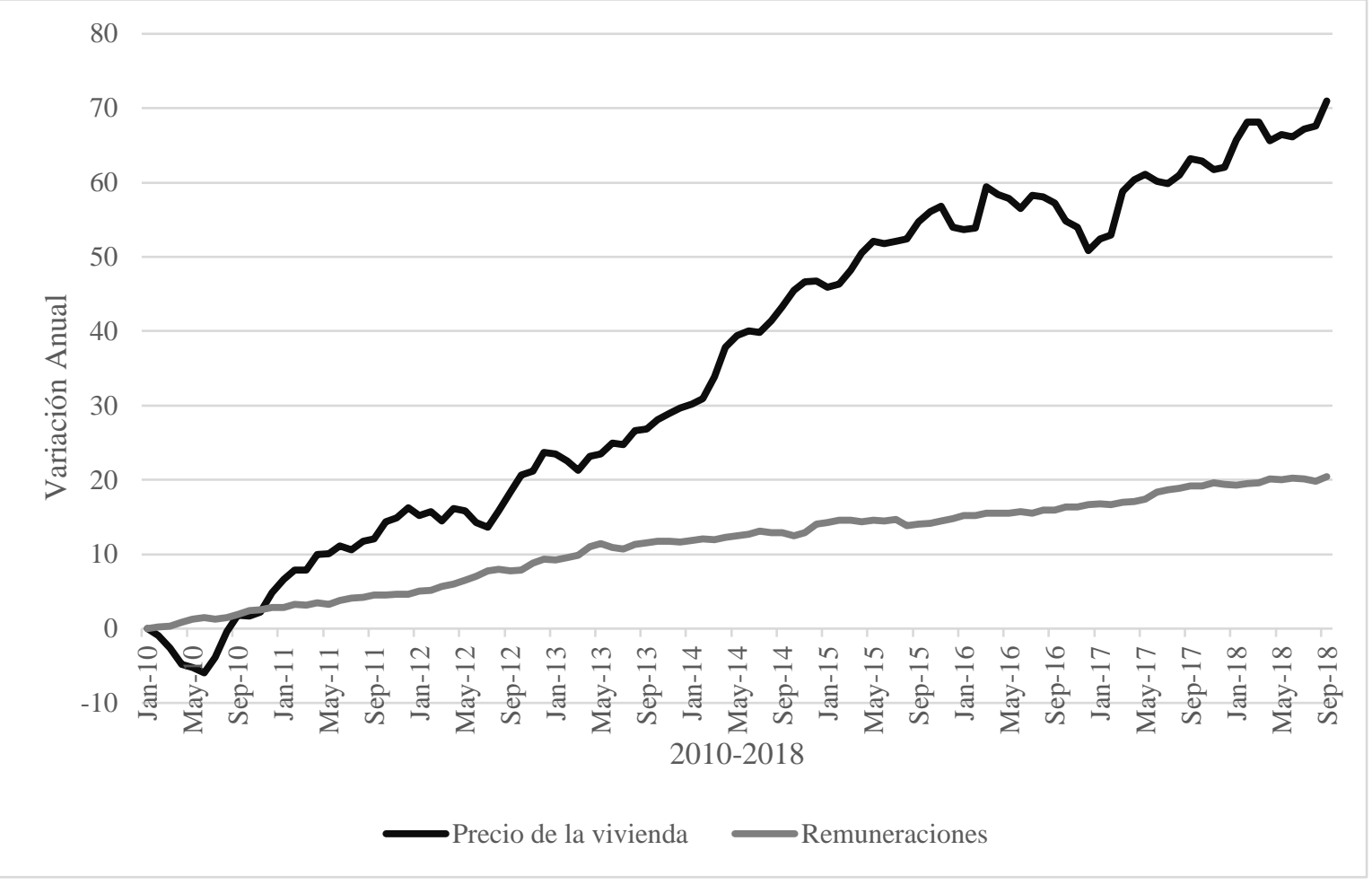

For the Central Bank of Chile, this situation is worrisome given that part of the purchase of new housing is being achieved by higher income sectors through debt mechanisms with financial institutions increasing the debt burden of households, where the greatest weight is due to mortgage loans (Central Bank, 2018). In this context, the role of financial institutions in the Chilean housing market was strengthened in 2001 through a reform of capital market regulations; and since then, a clear preference has developed among large companies to produce high-rise housing in sectors close to the $\mathrm{CBD}$ or metropolitan public transport corridors, generating a maximisation of financial exploitation of the land (Cattaneo Pineda, 2011). This is constituted as a characteristic of housing financing, which is no longer seen as a home but as a financial investment that is acquired to rent out more than to inhabit (Rolnik, 2013, 2017). In emblematic communes such as Santiago Centro, financialisation is represented spatially through an accelerated process of verticalisation of housing (Vergara, 2017).

Under the context of low regulation and neoliberalisation of urban development processes, housing is used for speculation (Encinas, Aguirre, Truffello, and Hidalgo, 2019), while households face serious difficulties in paying the price of housing, which in many cases ends up pushing them towards nearness, overcrowding or occupying land and developing informal housing (Vergaraperucich and Boano, 2018). As indicated in Table 1, a large part of households in Chile must spend more than $30 \%$ of household income on paying the price of housing, contravening the financial recommendations of households for this monthly expenditure (Herbert, Hermann, and Mccue, 2018; Schwartz and Willson, 2006). In the particular case of Santiago de Chile, the high price of housing against households' ability to pay could have serious consequences if a housing market bubble is confirmed, as suggested by Gil-Alana, Dettoni, Costamagna and Valenzuela (2019). 
TABLE 1. The weight of the rental price on the labour income of households. Source: Prepared by the authors based on the CASEN 2017 survey.

\begin{tabular}{|c|c|c|c|c|c|}
\hline District & I & II & III & IV & $\mathrm{V}$ \\
\hline Alhué & $42 \%$ & $39 \%$ & $25 \%$ & $23 \%$ & $8 \%$ \\
\hline Buin & $57 \%$ & $25 \%$ & $18 \%$ & $12 \%$ & $13 \%$ \\
\hline Calera de Tango & $37 \%$ & $19 \%$ & $20 \%$ & $17 \%$ & $10 \%$ \\
\hline Cerrillos & $89 \%$ & $27 \%$ & $31 \%$ & $19 \%$ & $14 \%$ \\
\hline Cerro Navia & $73 \%$ & $34 \%$ & $18 \%$ & $20 \%$ & $15 \%$ \\
\hline Colina & $68 \%$ & $37 \%$ & $25 \%$ & $21 \%$ & $11 \%$ \\
\hline Conchalí & $73 \%$ & $32 \%$ & $31 \%$ & $17 \%$ & $15 \%$ \\
\hline Curacaví & $88 \%$ & $50 \%$ & $23 \%$ & $18 \%$ & $18 \%$ \\
\hline El Bosque & $57 \%$ & $28 \%$ & $20 \%$ & $20 \%$ & $11 \%$ \\
\hline El Monte & $59 \%$ & $28 \%$ & $20 \%$ & $26 \%$ & $20 \%$ \\
\hline Estación Central & $82 \%$ & $46 \%$ & $35 \%$ & $27 \%$ & $13 \%$ \\
\hline Huechuraba & $72 \%$ & $41 \%$ & $23 \%$ & $20 \%$ & $10 \%$ \\
\hline Independencia & $125 \%$ & $42 \%$ & $30 \%$ & $21 \%$ & $20 \%$ \\
\hline Isla de Maipo & $48 \%$ & $29 \%$ & $21 \%$ & $24 \%$ & $26 \%$ \\
\hline La Cisterna & $72 \%$ & $41 \%$ & $35 \%$ & $23 \%$ & $12 \%$ \\
\hline La Florida & $76 \%$ & $44 \%$ & $30 \%$ & $21 \%$ & $15 \%$ \\
\hline La Granja & $71 \%$ & $38 \%$ & $26 \%$ & $19 \%$ & $24 \%$ \\
\hline La Pintana & $65 \%$ & $28 \%$ & $17 \%$ & $15 \%$ & $17 \%$ \\
\hline La Reina & $127 \%$ & $68 \%$ & $43 \%$ & $40 \%$ & $18 \%$ \\
\hline Lampa & $58 \%$ & $36 \%$ & $26 \%$ & $18 \%$ & $12 \%$ \\
\hline Las Condes & $184 \%$ & $98 \%$ & $54 \%$ & $49 \%$ & $21 \%$ \\
\hline Lo Barnechea & $106 \%$ & $50 \%$ & $29 \%$ & $37 \%$ & $19 \%$ \\
\hline Lo Espejo & $55 \%$ & $29 \%$ & $23 \%$ & $15 \%$ & $16 \%$ \\
\hline Lo Prado & $61 \%$ & $43 \%$ & $28 \%$ & $21 \%$ & $14 \%$ \\
\hline Macul & $97 \%$ & $40 \%$ & $30 \%$ & $23 \%$ & $20 \%$ \\
\hline Maipú & $89 \%$ & $44 \%$ & $29 \%$ & $21 \%$ & $13 \%$ \\
\hline María Pinto & $56 \%$ & $34 \%$ & $19 \%$ & $26 \%$ & $138 \%$ \\
\hline Melipilla & $51 \%$ & $36 \%$ & $25 \%$ & $13 \%$ & $10 \%$ \\
\hline Ñuñoa & $116 \%$ & $79 \%$ & $59 \%$ & $35 \%$ & $15 \%$ \\
\hline Padre Hurtado & $89 \%$ & $36 \%$ & $40 \%$ & $17 \%$ & $11 \%$ \\
\hline Paine & $85 \%$ & $30 \%$ & $24 \%$ & $18 \%$ & $20 \%$ \\
\hline Pedro Aguirre Cerda & $66 \%$ & $32 \%$ & $27 \%$ & $21 \%$ & $13 \%$ \\
\hline Peñaflor & $104 \%$ & $40 \%$ & $28 \%$ & $30 \%$ & $17 \%$ \\
\hline Peñalolén & $59 \%$ & $43 \%$ & $26 \%$ & $21 \%$ & $16 \%$ \\
\hline Pirque & $67 \%$ & $80 \%$ & $27 \%$ & $28 \%$ & $20 \%$ \\
\hline Providencia & $702 \%$ & $116 \%$ & $77 \%$ & $52 \%$ & $19 \%$ \\
\hline Pudahuel & $56 \%$ & $37 \%$ & $25 \%$ & $18 \%$ & $17 \%$ \\
\hline Puente Alto & $72 \%$ & $34 \%$ & $29 \%$ & $21 \%$ & $15 \%$ \\
\hline
\end{tabular}




Quilicura
Quinta Normal
Recoleta
Renca
San Bernardo
San Joaquín
San José de Maipo
San Miguel
San Pedro
San Ramón
Santiago
Talagante
Tiltil
Vitacura

\begin{tabular}{|c|c|c|c|c|}
\hline $68 \%$ & $40 \%$ & $26 \%$ & $21 \%$ & $14 \%$ \\
\hline $76 \%$ & $33 \%$ & $26 \%$ & $23 \%$ & $12 \%$ \\
\hline $94 \%$ & $38 \%$ & $30 \%$ & $22 \%$ & $11 \%$ \\
\hline $58 \%$ & $39 \%$ & $22 \%$ & $14 \%$ & $11 \%$ \\
\hline $51 \%$ & $27 \%$ & $24 \%$ & $19 \%$ & $14 \%$ \\
\hline $78 \%$ & $33 \%$ & $24 \%$ & $20 \%$ & $26 \%$ \\
\hline $121 \%$ & $46 \%$ & $30 \%$ & $30 \%$ & $19 \%$ \\
\hline $100 \%$ & $52 \%$ & $40 \%$ & $27 \%$ & $16 \%$ \\
\hline $62 \%$ & $19 \%$ & $36 \%$ & $16 \%$ & $\mathrm{n} / \mathrm{i}$ \\
\hline $76 \%$ & $33 \%$ & $26 \%$ & $15 \%$ & $9 \%$ \\
\hline $103 \%$ & $49 \%$ & $38 \%$ & $27 \%$ & $16 \%$ \\
\hline $99 \%$ & $28 \%$ & $33 \%$ & $25 \%$ & $15 \%$ \\
\hline $59 \%$ & $26 \%$ & $23 \%$ & $14 \%$ & $12 \%$ \\
\hline $\mathrm{n} / \mathrm{i}$ & $800 \%$ & $85 \%$ & $52 \%$ & $22 \%$ \\
\hline
\end{tabular}

In this article, we developed an exploratory study on the price of housing in the city of Santiago de Chile, in order to generate a diagnosis to identify the role played by expectations of profitability when configuring that price. Based on the information generated, we seek to contribute to the discussion on public policies that advance towards the development of affordable housing for households in central communes with high urban value, as is the case of Santiago Centro (Contreras Gatica, 2011). This is an inductive, exploratory and quantitative research, which works with data obtained from unified official files for the specific study of a set of projects of diverse typology located in the commune of Santiago Centro, corresponding to the local CBD. After presenting the methodology to be used, a systematic analysis is developed from the cost flow system on the price structure of high-rise housing projects located in the commune of Santiago Centro to determine what their expected returns are at the time of elaborating the proposals and which are the factors that most help explain the price of housing when a microeconomic analysis is generated. As an anticipation of the results obtained in the study, a large part of the price of the house is increased by the expectations that the investors of the project have regarding its initial profitability. A second part of the study indicates that if the profit expectations are modified, the price of the house will be drastically reduced. The research is relevant due to the lack of data transparency in the Chilean housing market, where access to investment costs, land values, yields and house price formation are not part of the public discussion, even though this implies that many households are facing severe difficulties in paying for access to decent housing.

\section{Study area}

The commune of Santiago de Centro is the capital of the Republic of Chile, configuring also its historical center (Martínez Lemoine, 2003) and its main receiver of urban workers (SECTRA, 2014). It is located in the center of the metropolitan area of Greater Santiago and also functions as the political center of the nation, given that in this place are located the main ministries, public services and the government palace. It has an area of $23 \mathrm{~km}^{2}$ and 404,495 inhabitants according to the National Population Census 2017 (National Statistics Institute (INE), 2018). This commune, in addition, concentrates an important quantity of recent developments as a consequence of the earthquake of the 
year 1985, in the first instance, and of the aggressive process of urban renovation initiated in the year 2000.
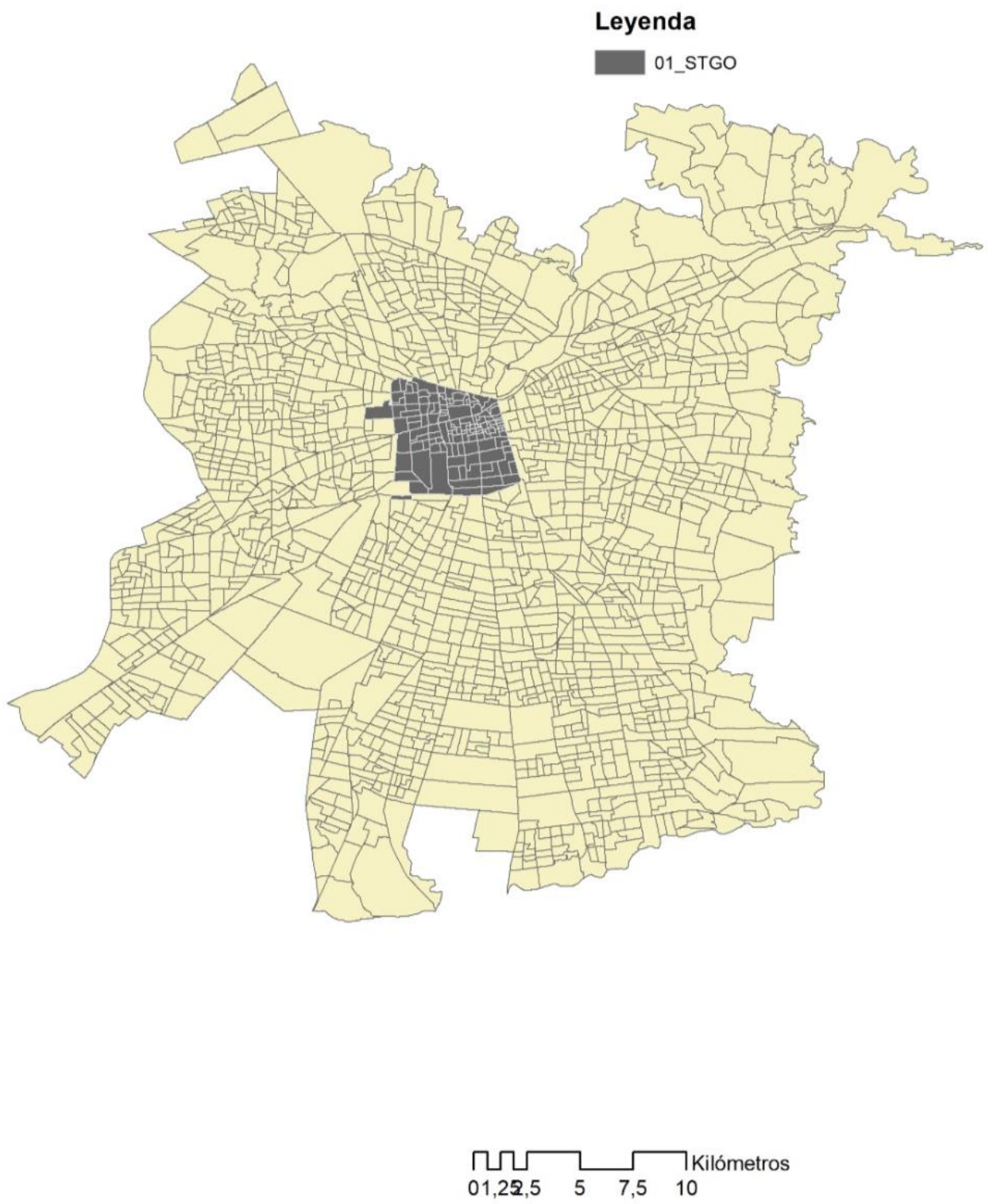

Figure 2. Santiago's district within the metropolitan area of Santiago. Source: authors.

For the earthquake of 1985, the commune of Santiago suffered multiple damages in the buildings, in that moment mainly made of adobe, whose reconstruction took years due to the delicate economic situation of the country in those years (D. Contreras and Ffrench-Davis, 2012). After the beginning of the transition to democracy which begun in 1990, a repopulation plan was implemented that provided special subsidies for the purchase of apartments in the commune. This plan made it possible to occupy a large part of the land that had become vacant after the earthquake and generated significant pressure for the purchase of land for the construction of buildings. The typologies of these buildings varied over the years. First, constructions of up to 5 floors were built, and later, works on 
higher buildings were started. As can be seen in Figure 3, there has been an increase in the heights of the approved building, highlighting that after 1995, buildings with less than 3 floors disappeared. In contrast, from 1995 to 2015, most records indicate that buildings of more than 16 floors predominated, marking a trend in the process of verticalisation of the city (Vergara, 2017).

Figure 3. Composition of new buildings in the commune of Santiago Centro between 1991 and 2018. Source: Own elaboration based on data from the National Institute of Statistics.

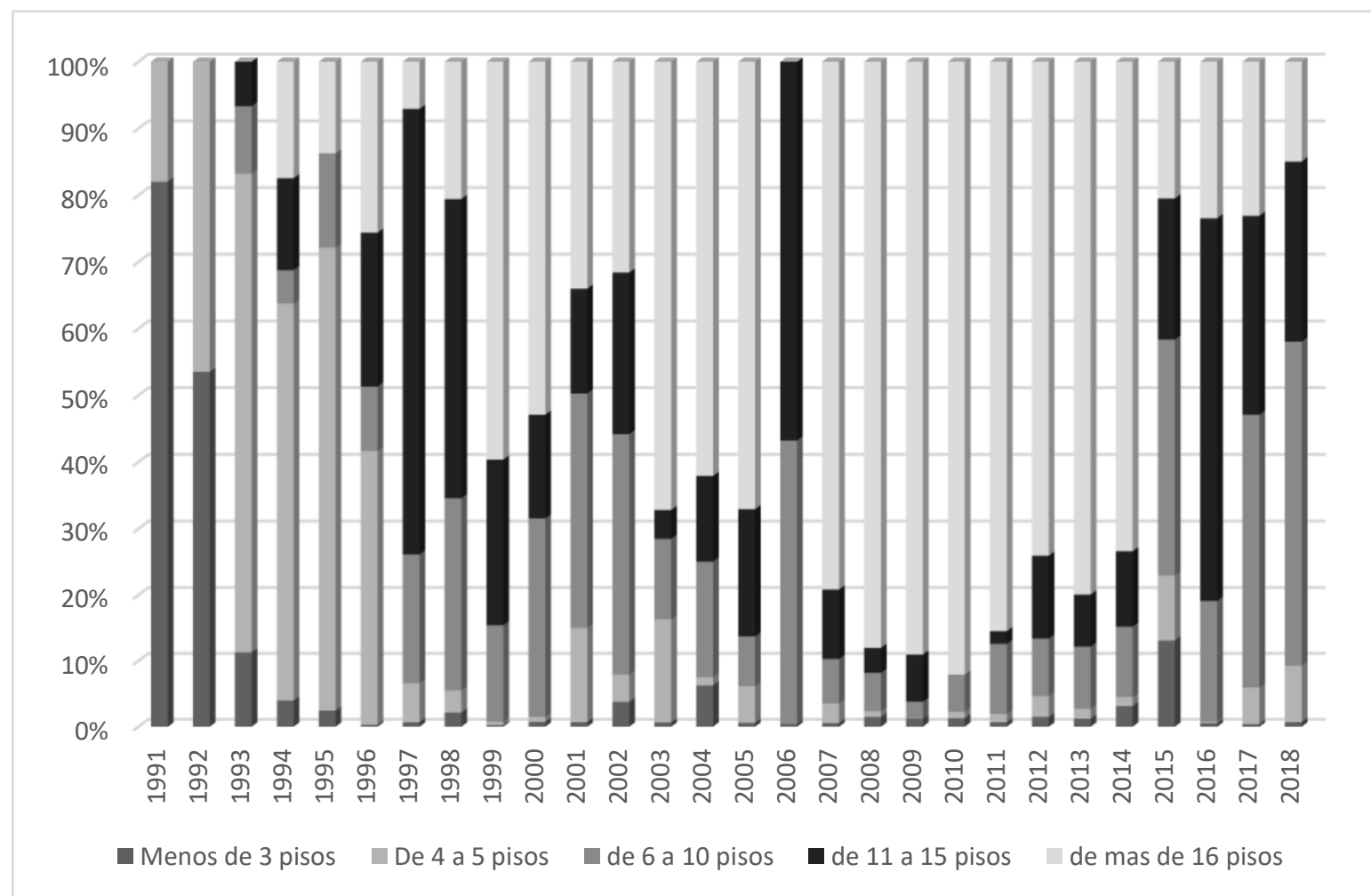

If we analyse medium-density buildings (up to 10 floors), medium-high-density buildings (those ranging from 11 to 15 floors) and high-density buildings (exceeding 16 floors), we observe fairly defined cycles of medium and medium-high-density buildings, versus high-density buildings. In the period between 1991 and 2018, the presence of low-rise housing is practically nil after 1995. The plan to repopulate downtown Santiago advanced against the city's expansive tendency towards its borders and determined a new urban form of the historic center, replacement of residents and increase in the value of land that was capitalised mainly by real estate companies (Contreras Gatica, 2011; Y. Contreras, 2010). In some sectors of the commune, these transformations began a process of gentrification due to the high values of the properties that were built on the land of former residents (Lopez Morales, Arriagada Luco, and Gasic Corvalan, 2015). With these socio-spatial conditions, recently developed literature has focused mainly on how subsidiary policies and local regulations have contributed to change the characteristics of the commune, however, little literature has explored how the prices of these new homes are configured in the private world. (Evans et al, 2017; Garreton, 2017b; Hidalgo Dattwyler, Christian Voltaire, and Santana Rivas, 2017). In part, this has been difficult due to the scarce access to information in the Chilean housing market; however, most of the provision of this good is done by private actors. 

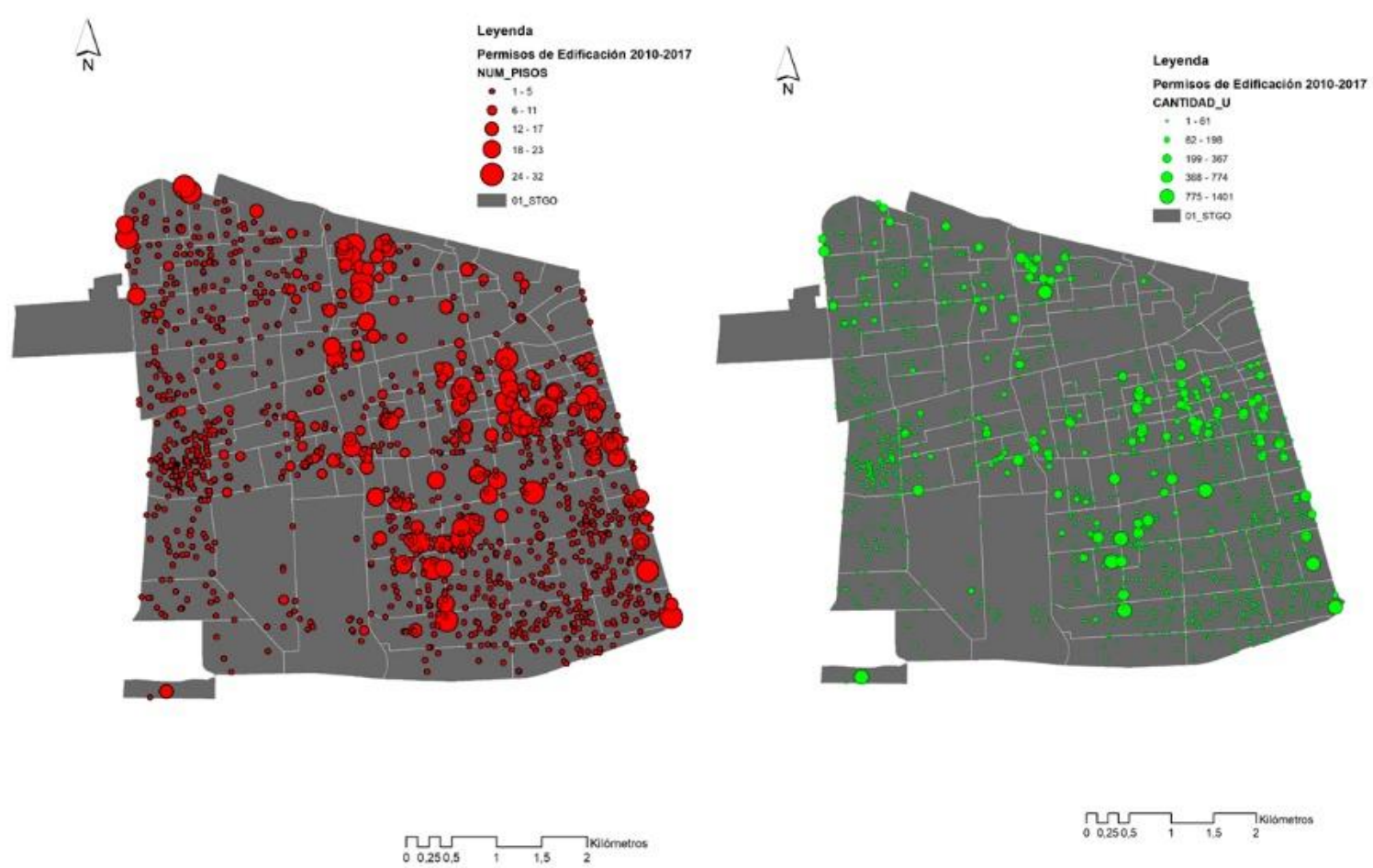

Figure 4. New buildings in Santiago. In red the number of floors, in green the number of new housing units. Source: Authors based on National Institute of Statistics. 


\section{Methods}

The method seeks to establish profitability expectations set by real estate agents to decide to invest in projects located in the commune of Santiago Centro. For this purpose, a model was developed that consists of 3 parts: a construction cost model, an income model and finally a general cash flow model of the project; this mechanism being the most used by real estate companies when deciding whether to invest in a housing project (Simian and Niklitschek, 2017). With this flow, the expected profitability of the projects is evaluated using a model of total financial efficiency, that is to say, it does not establish the separation between who the recipient of the profit is, if not the complete profit for the total sale of the project. This profit is analysed through the internal rate of return (IRR), the net present value (NPV), the estimated periods for the return of the investment and the costbenefit ratio of the investments from the IP or profitability index (Ginevičius and Zubrecovas, 2009). The use of this method is defined, to a large extent, by the possibility of accessing the data. It is a method widely validated by real estate developers both in Chile and in other nations, which allows the results to be comparable (Goddard and Marcum, 2012).

The construction cost model is based on a budget estimate associated with the level of terminations, equivalent to the replacement cost validation model of the Chilean Internal Revenue Service (SII). In addition, a rhythmic configuration of work progress was established, which transforms the total construction budget into a flow according to an ideal work progress, characteristic of high-rise construction, based on a S-curve model of construction project planning (Miskawi, 1989), where most of the investment is on the temporary half of the project. Considering the construction speeds in Chile, it is considered that the construction of the building will depend on the number of floors, advancing 1 floor for each month of advance. The rest of the flow is calculated from the sales speed of the project. It is important to mention that the sales speed of the project has also been elaborated based on data from each project. Finally, the profitability calculations of each analysed work are made on these flows.

Figure 5. Rhythmic model of progress of works for twelve months.

\begin{tabular}{|c|c|c|c|c|c|c|c|c|c|c|c|c|c|}
\hline \multicolumn{10}{|c|}{ Project construction flow; $\mathrm{j}$ 12 } \\
\hline Time (months) & 1 & 2 & 3 & 4 & 5 & 6 & 7 & 8 & 9 & 10 & 11 & 12 & Sum \\
\hline Progress (\%) & $1 \%$ & $3 \%$ & $4 \%$ & $8 \%$ & $14 \%$ & $20 \%$ & $20 \%$ & $14 \%$ & $8 \%$ & $4 \%$ & $3 \%$ & $1 \%$ & $100 \%$ \\
\hline Costs (UF) & $\mathrm{P}^{*} \%$ & - & - & - & - & - & - & - & - & - & $\mathrm{P}^{*} \%$ & $\mathrm{P}^{*} 1 \$$ & - \\
\hline
\end{tabular}

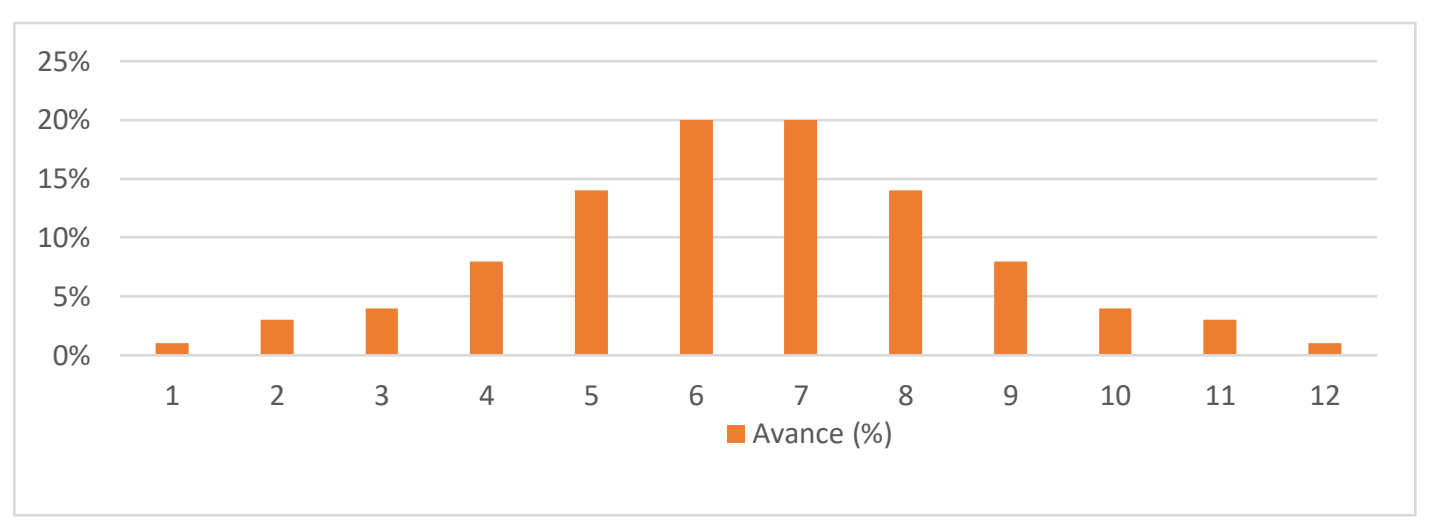


The revenue model is to determine a start, end and pace of sales in a given period. As an assumption, the sales speed declared in the InCiti platform database was considered and contrasted with the data declared by the Chilean Construction Chamber. The assumption that monthly sales develop steadily based on the sales rate recorded until the stock of available housing is exhausted was used.

To summarise, there are three key moments in this estimate, the start of green sales, the completion of the work and sales once the work is completed. For the case of Santiago, when start the construction process also start the sales (opening of the department for sales or pilot for the third month) to the completion of work and municipal approvals (duration of construction works plus three months). In Chile, it is customary for real estate projects to sell green, accruing $20 \%$ of the value of the home in the month of sale and displacing the remaining $80 \%$ to the period immediately following the municipal receptions of the terminal works. In other words, the green foot is charged and the remaining $80 \%$ is paid after the municipal reception for the total of the department. We have not considered discounts or offers, but fixed values based on transactions registered at the Conservador de Bienes Raíces de Santiago. After the receptions of finished work, the units are sold accruing the total of its sale price. For this model, an average cost per square meter of sale was assumed according to the data of each existing department.

The financial evaluation model was carried out through a cash flow construction exercise considering the initial period (zero), the value of the land purchase, project expenses and permits. For monthly periods, the flow of income and expenses are calculated before the IRR and NPV indicators.

TABLE 2. Cash flow analysis model. Source: Authors.

\begin{tabular}{|c|c|c|c|c|c|c|c|c|c|c|c|c|c|c|c|c|c|c|c|c|}
\hline \multirow{2}{*}{$\begin{array}{c}\text { Cash Flow } \\
\text { TIME }\end{array}$} & \multirow{2}{*}{\begin{tabular}{c|} 
Zer \\
o \\
0
\end{tabular}} & \multicolumn{5}{|c|}{$\begin{array}{c}\text { SALE IN GREEN } \\
\text { (Before you } \\
\text { finish) }\end{array}$} & \multicolumn{3}{|c|}{ Reception } & \multicolumn{10}{|c|}{$\begin{array}{l}\text { Sale in Grey (finished work and } \\
\text { received) }\end{array}$} & \multirow[t]{2}{*}{$\begin{array}{c}\text { Tota } \\
1\end{array}$} \\
\hline & & 1 & 2 & 3 & $\ldots$ & $\mathrm{j}$ & $\mathrm{j}+1$ & & $\begin{array}{l}j+ \\
3 \\
\end{array}$ & $\begin{array}{c}\mathrm{j}+ \\
4 \\
\end{array}$ & $\ldots$ & $\cdots$ & $\cdots$ & $\cdots$ & .. & & $\cdots$ & & $\mathrm{n}$ & \\
\hline Units Sold & - & - & - & - & - & - & - & - & - & - & - & - & - & - & - & - & - & & - & \\
\hline Income & - & - & - & - & - & - & - & - & - & - & - & - & - & - & - & - & - & - & - & \\
\hline Income by PIE & - & - & - & - & - & - & - & - & - & - & - & - & - & - & - & - & - & & - & \\
\hline Mortgage Income & - & - & - & - & - & - & - & - & - & - & - & - & - & - & - & - & - & - & - & \\
\hline Land Cost & - & - & - & - & - & - & - & - & - & - & - & - & - & - & - & - & - & 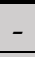 & - & \\
\hline Construction Costs & - & - & - & - & - & - & - & - & - & - & - & - & - & - & - & - & - & - & - & \\
\hline Consultancy Costs & - & - & - & - & - & - & - & - & - & - & - & - & - & - & - & - & - & - & - & \\
\hline Permit Costs & - & - & - & - & - & - & - & - & - & - & - & - & - & - & - & - & - & - & - & \\
\hline Marketing Costs & - & - & - & - & - & - & - & - & - & - & - & - & - & - & - & - & - & - & - & \\
\hline Cash Flow & & & & & & & & & & & & & & & & & & & & \\
\hline
\end{tabular}

It is important to mention that the housing market in Chile does not function on the basis of transparent data. On one hand, housing prices are only recorded on paper (not digital) files that are stored by real estate curators depending on each territory, in this case Santiago. On the other hand, the amounts of investment in construction are not publicly registered by all companies. This is only mandatory for large projects, which is incorporated into the Environmental Evaluation System when entering projects to be evaluated and approved. This information is provided by the company itself. 
Another limitation is that the fiscal appraisal of real estate is completely distanced from the commercial appraisal of the same. This means that, among other things, real estate transactions pay taxes against the tax assessment, so that the Internal Revenue Service does not necessarily handle information on the commercial costs of building works. This has led to some methodological decisions being made on how to deal with the evaluation of each project.

The following sources have been used to obtain the data:

1. Conservador de Bienes Raíces de Santiago, public entity that registers property transactions in the city, indicating personal data of those who carry out the transactions, values, dimensions and general characteristics of each property. This information was obtained from data collected by InCiti.

2. Speed of sale of the properties to determine their construction times, prepared based on data from the Chilean Chamber of Construction and the background of project progress collected by InCiti.

3. The definitive amounts of investment by projects were not available for each of the cases, but it has served to test the veracity of the data obtained from other sources to review whether the announced investments are in accordance with the calculated returns. For this information, the Environmental Assessment Service of the Ministry of the Environment has been consulted.

4. For the estimation of construction costs, we have developed a calculation based on data obtained from the catalogue of construction activities ONDAC and the estimation tables developed by the Internal Revenue Service and the Ministry of Housing and Urban Development. Depending on the volume constructed, we have used a construction value of UF/m2 estimated at 22.5 to 25 for construction above level 0; and $17 \mathrm{UF} / \mathrm{m} 2$ for construction of subways. These values are net.

5. In order to estimate the income from sales projects, the commercial value advertised on specialised websites (portalinmobiliario.com and toctoc.com) has been used, contrasting it with the transaction information indicated in InCiti's databases and in the advertisements of the companies that commercialised their works.

6. To the final investment costs, the expenses corresponding to advertising and sales, consulting and project design have been added.

7. To illustrate the role of financial entities and their impact on the profitability of a project when it requests bank loans to execute the works, a set of results has been developed that exposes some projects with bank financing indicating their percentage of total investment and others only based on own resources.

\section{Reconstruction of the history of evaluated projects}

Given that the housing market in Chile is presented without full transparency in obtaining the data, the reconstruction of the history of each project had to follow a detailed process that is illustrated below with a case of a revised building $\left(\mathrm{N}^{\circ} 1\right)$. This is a 1- and 2-bedroom building, from which the real estate company projects general profits of UF $1,532,000$; equivalent to $22 \%$ of the projected profits for newly completed projects. In our evaluation these amounts are complemented with other project information contained in their building permits and transactions, which made us correct the sales amount by $9.09 \%$. These profits are declared in the annual report of the company, in relation to its projections for the year 2019. This report is available in the Chilean Superintendence of Securities and Insurance. Having these expectations of profits as a reference, the detail of the same project is reviewed, for which we have access to its planimetric background, building permits, environmental impact statement and transactions in the Santiago Real Estate Conservative (CBRS). As a general context, the project is governed by the regulations of the Communal Regulatory Plan of 
Santiago Centro. This project obtained its building permit on June 18, 2018, adapting to the standards indicated in the Certificate of Previous Reports 153.610 of 2016 (Zone B of the PRC of Santiago). For this project, 546 apartments to be sold are contemplated, with an estimated cost of $68 \mathrm{UF} / \mathrm{m} 2$ for each one. In other words, a department of $35 \mathrm{~m} 2$ would cost UF 2726. In the Environmental Evaluation System, the company declares that the investment to execute the project is of the order of UF 694,374. To this amount, we have added the cost the land incurred for its construction, dimensioned in 4.612 $\mathrm{m}^{2}$, registered in the register of the Internal Revenue Service with the ROL 634-3 to 634-9, whose tax assessment is 54.139 UF and sales value registered in the CBRS sheet 80.755-80.778 was UF 245.364. The building has 6 different types of apartments, on 12 floors, covering 19,317 $\mathrm{m}^{2}$ for sale, plus 208 parking lots and warehouses sold at UF 400 and UF 55 respectively. It is considered a construction flow based on the S-curve model, where one floor is built per month. According to the speed of sale registered in this project, the sale of all the work is calculated in 25 months. The applied construction cost is $22 \mathrm{UF} / \mathrm{m}^{2}$ for surface construction and $15 \mathrm{UF} / \mathrm{m}^{2}$ for underground construction. No bank financing is considered for the evaluation of this project. Then, with these real data, which can be consulted in the sources of origin, the profitability of the project and its expectations of profits are evaluated using a methodology based on the flows of the project. The results applied to the evaluation of this project can be reviewed in numeral 1 of Table 4 . This procedure was applied to each project presented in the table.

\section{Analysis techniques}

On the main financial analysis techniques used in this document, the Net Present Value, the Internal Rate of Return and the Cost-Benefit analysis are detailed.

The net present value is a procedure that calculates the present value of a certain number of future financial flows generated by an investment. It is calculated by applying a current discount rate to all future cash flows, simulating what the gains would be if the cash flows were brought to the present in order to compare these gains with the initial investment. The discount rate (d) is the result of the product between the weighted average cost of capital (WACC) and the inflation rate for the period. For these projects, a discount rate of $12 \%$ has been applied. If the NPV is greater than 0 (i.e. exceeds the initial investment), the project is considered a recommended investment.

The NPV formula is:

$$
N P V=\sum_{i}^{n}-I+\frac{R\left[1-(1+i)^{-n}\right]}{i}
$$

Where,

$$
\mathrm{R}=\text { net cash flow }
$$

$\mathrm{n}=$ number of periods

$\mathrm{i}=$ discount rate $(12 \%)$

To complement the profitability analysis based on the NPV, a profitability estimate has been applied to each project according to the internal rate of return IRR (Manganelli, 2015). The internal rate of return reviews the geometric mean of the return on an investment to determine the value of the opportunity. The higher the internal rate of return, the higher the expected return on an investment which thus determines whether the investments are worthwhile or not (Ferson, 2013). 
Its calculation is based on the following formula:

$$
I R R, \text { tal que }, \sum_{n=0}^{n} \frac{C F_{n}}{(1+I R R)^{n}}=N P V=0
$$

Where,

$\mathrm{CF}=$ Cash Flow

$\mathrm{n}=$ each period

NPV $=$ Net Present Value

IRR= Internal Rate of Return

Finally, the profitability index (PI) is calculated to determine the cost-benefit ratio of the investment. This is a calculation that is carried out using the NPV and offers a third analysis factor on the profitability of the projects to be analysed. It is a simple method that is developed based on the following formula:

$$
P I=\frac{(N P V+I)}{I}
$$

Where,

$$
\text { PI }=\text { Profitability Index }
$$$$
\text { NPV }=\text { Net Present Value }
$$

$\mathrm{I}=$ Investment $\mathrm{I}$.

Monetary values have been expressed in UF, which is a monetary index used in Chile for different products (including real estate products) that is adjusted daily according to variations in the

\begin{tabular}{|c|c|}
\hline Dato & Fuente \\
\hline Property Size (m2) & Conservador de Bienes Raíces de Santiago mediante InCiti.com \\
\hline Total Land Value (UF) & Conservador de Bienes Raíces de Santiago mediante InCiti.com \\
\hline Land Value (UF/m2) & Conservador de Bienes Raíces de Santiago mediante InCiti.com \\
\hline Building floors (n) & Expediente del proyecto de InCiti.com \\
\hline Units of Departments for Sale (n) & Expediente del proyecto de InCiti.com \\
\hline $\begin{array}{c}\text { Average surface area of the } \\
\text { departments }\left(\mathrm{m}^{2}\right)\end{array}$ & Expediente del proyecto de InCiti.com \\
\hline $\begin{array}{l}\text { Built surface on level } 0 \text { of the } \\
\text { building }\left(\mathrm{m}^{2}\right)\end{array}$ & $\begin{array}{c}\text { Estimación a partir de exigencias del Plan Regulador Comunal Vigente } \\
\text { en Santiago Centro }\end{array}$ \\
\hline $\begin{array}{l}\text { Built Surface Subterranean of the } \\
\text { building }\left(\mathrm{m}^{2}\right)\end{array}$ & Estimación a partior de cantidad de estacionamientos y tamaño predial \\
\hline $\begin{array}{l}\text { Surface area of apartments for sale } \\
\qquad\left(\mathrm{m}^{2}\right)\end{array}$ & Expediente del proyecto de InCiti.com \\
\hline Number of Parking Lots for Sale (n) & Expediente del proyecto de InCiti.com \\
\hline
\end{tabular}
CPI. For this analysis, a UF equivalent to $£ 32.64$; $€ 35.21$ or USD39.41 was used.

TABLE 3. Data Sheet for Profitability Evaluation. Source: Authors. 


\begin{tabular}{|c|c|} 
Number of Warehouses for Sale (n) & Expediente del proyecto de InCiti.com \\
\hline Built Surface $\left(\mathrm{m}^{2}\right)$ & Expediente del proyecto de InCiti.com \\
\hline Sales Value of Apartments (UF/m $\left.\mathrm{m}^{2}\right)$ & Portalinmobiliario, Toctoc.com y sitio web de empresa \\
\hline Parking Sales Value (UF) & Expediente del proyecto de InCiti.com \\
\hline Sale Value of Warehouses (UF) & Expediente del proyecto de InCiti.com \\
\hline Initial Investment (UF) & - \\
\hline Income (UF) & - \\
\hline
\end{tabular}

As a synthesis, the evaluation of total construction costs has been done following the cost structure model presented by Dr Julio Aznares in a publication that was developed under the auspices of local real estate companies and, therefore, we understand that it is a model validated by the local industry (Simian and Niklitschek, 2017). The following table synthesises this cost structure and details how the data has been obtained.

Table 4. Project cost structure. Source: authors.

\begin{tabular}{|c|c|c|}
\hline Item & $\begin{array}{l}\text { val } \\
\text { ue }\end{array}$ & Source \\
\hline Land (uf, CBR) ${ }^{* *}$ & $\begin{array}{c}\text { Uni } \\
\text { ts }\end{array}$ & Conservador de Bienes Raíces de Santiago \\
\hline Cost of construction on $0(\mathrm{uf})^{* * *}$ & 22 & $\begin{array}{l}\text { Estimación desarrollada por el Servicio de } \\
\text { Impuestos Internos }\end{array}$ \\
\hline Underground construction cost (uf) & 15 & $\begin{array}{l}\text { Estimación desarrollada por el Servicio de } \\
\text { Impuestos Internos }\end{array}$ \\
\hline Municipal rights $(0,12 \mathrm{uf} / \mathrm{m} 2)^{* * * *}$ & 0,11 & Ley General de Urbanismo y Construcciones \\
\hline $\begin{array}{l}\text { Architectural and engineering study (on } \\
\text { construction cost) }\end{array}$ & $5 \%$ & $\begin{array}{c}\text { Aranceles Referenciales del Colegio de } \\
\text { Arquitectos de Chile }\end{array}$ \\
\hline Calculation study (uf/m2)* & 0,2 & $\begin{array}{c}\text { Aranceles Referenciales del Colegio de } \\
\text { Arquitectos de Chile }\end{array}$ \\
\hline Landscaping (obras, uf/m2) & 2,5 & $\begin{array}{c}\text { Aranceles Referenciales del Colegio de } \\
\text { Arquitectos de Chile }\end{array}$ \\
\hline Landscaping design (on landscaping) ${ }^{* * *}$ & $\begin{array}{c}4,00 \\
\%\end{array}$ & $\begin{array}{c}\text { Aranceles Referenciales del Colegio de } \\
\text { Arquitectos de Chile }\end{array}$ \\
\hline Administration (construction costs) ${ }^{*}$ & $2 \%$ & $\begin{array}{c}\text { Aranceles Referenciales del Colegio de } \\
\text { Arquitectos de Chile }\end{array}$ \\
\hline Marketing and sales (on construction) & $8 \%$ & Aznares en Simian et al. 2017 \\
\hline Legal expenses (on construction) & $2 \%$ & Aznares en Simian et al. 2017 \\
\hline Income Taxes & $10 \%$ & Servicio de Impuestos Internos \\
\hline V.A.T. & $\begin{array}{c}6,65 \\
\%\end{array}$ & Servicio de Impuestos Internos \\
\hline Sales speed(month) & 36 & Cámara Chilena de la Construcción \\
\hline
\end{tabular}


From the information of the autonomous income of the household for the commune of Santiago Centro (MIDESO, 2018), it has been possible to determine what the weight of the purchase of the dwelling would be in relation to the payment capacity of the households. In order to carry out this evaluation, a credit with an annual rate of $4 \%$ has been simulated, for a period of 30 years, for the total cost of ownership. It is important to mention that, since the 2008 crisis, in Chile, financial institutions do not deliver loans for $100 \%$ of the value of properties, so this exercise has been carried out to represent how much the weight of the housing payment varies in a household when returns are adjusted. For this purpose, an exploration was also carried out on the possibility of reducing sales prices to adjust yields measured in CIRR between $12 \%$ and $16 \%$ while maintaining a positive NPV and PI. These adjustments were made on the sales price per square metre of the projects.

\section{Results}

The systematic evaluation of 15 projects was carried out in order to ascertain their presumed cost-effectiveness in relation to their initial evaluation. Table 4 summarises the expected gains for the projects analysed in the commune of Santiago Centro. On average, the projects evaluated have 16 floors, a gain measured by net present value of USD 7,139,245 (UF 181,153) and a Corrected Internal Rate of Return of $88 \%$. Not all projects were evaluated on the basis of bank loans. This has been done to illustrate how the profitability and risk of projects vary when incorporating the share of bank financing.

TABLE 5. Profitability of real estate projects in the commune of Santiago Centro. Source: Prepared by the authors based on data from the Santiago Real Estate Conservator, InCiti.com and the Environmental Assessment Service of the Ministry of the Environment.

\begin{tabular}{|c|c|c|c|c|c|c|c|c|c|c|c|}
\hline $\begin{array}{c}\text { Projec } \\
\mathrm{t} \text { N\# }\end{array}$ & $\begin{array}{l}\text { Flo } \\
\text { ors } \\
\text { (n) }\end{array}$ & $\begin{array}{c}\text { Investm } \\
\text { ent }\end{array}$ & Sales & NPV & $\begin{array}{l}\mathrm{CI} \\
\mathrm{R} \\
\mathrm{R}\end{array}$ & PI & $\begin{array}{l}\text { Pric } \\
\text { e } \\
(\mathrm{UF} \\
\left./ \mathrm{m}^{2}\right)\end{array}$ & $\begin{array}{c}\text { Fina } \\
\text { ncial } \\
\text { Aid }\end{array}$ & $\begin{array}{l}\text { Price } \\
\text { for } 50 \\
\mathrm{~m}^{2} \text { flat }\end{array}$ & $\begin{array}{c}\text { Wei } \\
\text { ght } \\
\text { of } \\
\text { pric } \\
\text { e } \\
\text { ove } \\
\text { r } \\
\text { mo } \\
\text { nthl } \\
\text { y } \\
\text { inco } \\
\text { me }\end{array}$ & $\begin{array}{l}\text { Land } \\
\text { Value }\end{array}$ \\
\hline 1 & 12 & 985.952 & $\begin{array}{c}1.408 .1 \\
96\end{array}$ & $\begin{array}{c}231.69 \\
7\end{array}$ & $\begin{array}{l}56 \\
\%\end{array}$ & $\begin{array}{c}1, \\
23 \\
5 \\
\end{array}$ & 68 & $0 \%$ & 3.400 & $43 \%$ & 50 \\
\hline 2 & 9 & 577.233 & $\begin{array}{c}969.81 \\
5\end{array}$ & $\begin{array}{c}248.04 \\
1\end{array}$ & $\begin{array}{c}10 \\
2 \\
\%\end{array}$ & $\begin{array}{c}1, \\
43 \\
0\end{array}$ & 64 & $0 \%$ & 4.250 & $44 \%$ & 36,01 \\
\hline 3 & 39 & 620.544 & $\begin{array}{c}812.56 \\
5\end{array}$ & 84.571 & $\begin{array}{l}36 \\
\%\end{array}$ & $\begin{array}{c}1, \\
13 \\
6\end{array}$ & 87 & $0 \%$ & 3.250 & $34 \%$ & 35,29 \\
\hline
\end{tabular}




\begin{tabular}{|c|c|c|c|c|c|c|c|c|c|c|c|}
\hline 4 & 12 & 531.663 & $\begin{array}{c}923.37 \\
2\end{array}$ & $\begin{array}{c}251.70 \\
0\end{array}$ & $\begin{array}{c}11 \\
1 \\
\%\end{array}$ & $\begin{array}{c}1, \\
47 \\
3\end{array}$ & 67 & $0 \%$ & 3.600 & $38 \%$ & 44,19 \\
\hline 5 & 12 & 397.717 & $\begin{array}{c}652.69 \\
4\end{array}$ & $\begin{array}{c}159.01 \\
4\end{array}$ & $\begin{array}{l}94 \\
\%\end{array}$ & $\begin{array}{c}1 \\
40 \\
0\end{array}$ & 66 & $0 \%$ & 3.600 & $38 \%$ & 29,01 \\
\hline 6 & 9 & 368.949 & $\begin{array}{c}629.80 \\
6\end{array}$ & $\begin{array}{c}165.93 \\
2\end{array}$ & $\begin{array}{c}10 \\
9 \\
\%\end{array}$ & $\begin{array}{c}1, \\
45 \\
0\end{array}$ & 66 & $0 \%$ & 4.100 & $43 \%$ & 17,75 \\
\hline 7 & 9 & 336.758 & $\begin{array}{c}435.88 \\
5\end{array}$ & 42.955 & $\begin{array}{l}32 \\
\%\end{array}$ & $\begin{array}{c}1, \\
12 \\
8\end{array}$ & 60 & $0 \%$ & 4.080 & $43 \%$ & 92,00 \\
\hline 8 & 9 & 247.605 & $\begin{array}{c}456.81 \\
7\end{array}$ & $\begin{array}{c}140.31 \\
8\end{array}$ & $\begin{array}{c}16 \\
8 \\
\%\end{array}$ & $\begin{array}{c}1, \\
56 \\
7\end{array}$ & 64 & $0 \%$ & 3.355 & $35 \%$ & 17,49 \\
\hline 9 & 9 & 66.762 & 98.726 & 18.145 & $\begin{array}{l}66 \\
\%\end{array}$ & $\begin{array}{c}1, \\
27 \\
2 \\
\end{array}$ & 53 & $0 \%$ & 3.300 & $35 \%$ & 12,02 \\
\hline 10 & 14 & 633.203 & $\begin{array}{c}1.059 .3 \\
59\end{array}$ & $\begin{array}{c}268.91 \\
2\end{array}$ & $\begin{array}{l}96 \\
\%\end{array}$ & $\begin{array}{c}1 \\
42 \\
5\end{array}$ & 63 & $0 \%$ & 4.350 & $45 \%$ & 48,09 \\
\hline 11 & 15 & 289.006 & $\begin{array}{c}402.79 \\
2\end{array}$ & 59.294 & $\begin{array}{l}49 \\
\%\end{array}$ & $\begin{array}{c}1, \\
20 \\
5\end{array}$ & 67 & $0 \%$ & 3.300 & $35 \%$ & 41,03 \\
\hline 12 & 26 & 934.941 & $\begin{array}{c}1.570 .4 \\
30\end{array}$ & $\begin{array}{c}405.82 \\
7\end{array}$ & $\begin{array}{c}10 \\
9 \\
\%\end{array}$ & $\begin{array}{c}1, \\
43 \\
4\end{array}$ & 75 & $0 \%$ & 3.400 & $36 \%$ & 38,54 \\
\hline 13 & 19 & 371.002 & $\begin{array}{c}437.64 \\
3 \\
\end{array}$ & 13.248 & $\begin{array}{l}19 \\
\%\end{array}$ & $\begin{array}{c}1, \\
03 \\
6 \\
\end{array}$ & 46 & $0 \%$ & 2.300 & $24 \%$ & 12,01 \\
\hline 14 & 24 & 440.603 & $\begin{array}{c}598.04 \\
0\end{array}$ & 77.584 & $\begin{array}{l}47 \\
\%\end{array}$ & $\begin{array}{c}1, \\
17 \\
6\end{array}$ & 82 & $0 \%$ & 2.750 & $29 \%$ & 25,90 \\
\hline 15 & 21 & 936.498 & $\begin{array}{c}1.257 .2 \\
00\end{array}$ & $\begin{array}{c}154.61 \\
3\end{array}$ & $\begin{array}{l}44 \\
\%\end{array}$ & $\begin{array}{c}1, \\
16 \\
5\end{array}$ & 55 & $0 \%$ & 2.650 & $28 \%$ & 22,00 \\
\hline
\end{tabular}

From Table 5, it can be reviewed that a high land value is not necessarily related to the yields obtained and to the same price of the dwelling. In the evaluation of the weight of these values of the housing on the payment capacity of the households, it is identified that they represent $35 \%$ of the average of the autonomous income of the household in the commune of Santiago Centro. In an evaluation of the cost of a department of $50 \mathrm{~m}^{2}$ for the projects, an average price of UF 3.336 is arrived at, which in averagely equivalent to 73 monthly household income, or 6 years of income per household. To explore whether companies could offer homes at lower prices without losing investment returns by altering the selling price per square meter of each home, it follows that its price could be reduced by an average of $29 \%$, compromising a $25 \%$ reduction in profitability measured by 
PI. The detail of the transformation after lowering the price per square meter sold is presented in the following table.

TABLE 6. Evaluation of the house price by adjusting the UF $/ \mathrm{m}^{2}$ value of the projects to be marketed, maintaining a CIRR between $10 \%$ and $16 \%$ as a range, safeguarding that PI is above 1 and ensuring that the NPV exceeds 2500 UF. Source: authors.

\begin{tabular}{|c|c|c|c|c|c|c|c|c|}
\hline $\begin{array}{c}\text { Projec } \\
\text { t N\# }\end{array}$ & $\begin{array}{l}\text { New } \\
\text { NPV } \\
\text { (UF) }\end{array}$ & $\begin{array}{l}\text { Adapte } \\
\text { d CIRR }\end{array}$ & PI & $\begin{array}{c}\text { Affordabl } \\
\text { e Price } \\
\text { (UF/m2) }\end{array}$ & $\begin{array}{l}\text { Housing } \\
\text { Price } \\
\text { Reductio } \\
\text { n }\end{array}$ & $\begin{array}{c}\text { Profitabilit } \\
\mathbf{y} \\
\text { Reduction }\end{array}$ & $\begin{array}{c}\text { Adapte } \\
\text { d Price } \\
\text { for } 50 \\
\mathrm{~m} 2 \text { flat }\end{array}$ & $\begin{array}{l}\text { Weight } \\
\text { of } \\
\text { adapte } \\
\text { d price } \\
\text { over } \\
\text { montly } \\
\text { income }\end{array}$ \\
\hline & & $12 \%$ & 1,014 & 53 & $-25 \%$ & $-22 \%$ & & $27 \%$ \\
\hline \multirow[t]{2}{*}{1} & 2.587 & & & & & & 2.550 & \\
\hline & & $12 \%$ & 1,003 & 48 & $-24 \%$ & $-20 \%$ & 2400 & $25 \%$ \\
\hline \multirow[t]{2}{*}{2} & 1.749 & & & & & & & \\
\hline & & $12 \%$ & 1,014 & 52 & $-13 \%$ & $-12 \%$ & 2600 & $27 \%$ \\
\hline \multirow[t]{2}{*}{3} & 9.018 & & & & & & & \\
\hline & & $12 \%$ & 1,015 & 43 & $-36 \%$ & $-29 \%$ & 2150 & $22 \%$ \\
\hline \multirow[t]{2}{*}{4} & 12.436 & & & & & & & \\
\hline & & $15 \%$ & 1,020 & 40 & $-38 \%$ & $-31 \%$ & 2000 & $21 \%$ \\
\hline \multirow[t]{2}{*}{5} & 7.463 & & & & & & & \\
\hline & & $13 \%$ & 1,009 & 46 & $-44 \%$ & $-38 \%$ & 2300 & $24 \%$ \\
\hline \multirow[t]{2}{*}{6} & 3.119 & & & & & & & \\
\hline & & $14 \%$ & 1,005 & 63 & $-23 \%$ & $-21 \%$ & 3125 & $33 \%$ \\
\hline \multirow[t]{2}{*}{7} & 1.647 & & & & & & & \\
\hline & & $16 \%$ & 1,037 & 32 & $-52 \%$ & $-44 \%$ & 1600 & $17 \%$ \\
\hline \multirow[t]{2}{*}{8} & 9.173 & & & & & & & \\
\hline & & $14 \%$ & 1,021 & 48 & $-36 \%$ & $-31 \%$ & 2400 & $25 \%$ \\
\hline \multirow[t]{2}{*}{9} & 8.185 & & & & & & & \\
\hline & & $12 \%$ & 1,002 & 54 & $-38 \%$ & $-34 \%$ & 2700 & $28 \%$ \\
\hline \multirow[t]{2}{*}{10} & 1.051 & & & & & & & \\
\hline & & $13 \%$ & 1,003 & 50 & $-24 \%$ & $-21 \%$ & 2500 & $26 \%$ \\
\hline \multirow[t]{2}{*}{11} & 1.003 & & & & & & & \\
\hline & & $13 \%$ & 1,004 & 52 & $-21 \%$ & $-18 \%$ & 2600 & $27 \%$ \\
\hline \multirow[t]{2}{*}{12} & 2.487 & & & & & & & \\
\hline & & $15 \%$ & 1,015 & 36 & $-21 \%$ & $-16 \%$ & 1800 & $19 \%$ \\
\hline \multirow[t]{2}{*}{13} & 5.512 & & & & & & & \\
\hline & & $13 \%$ & 1,009 & 43 & $-22 \%$ & $-20 \%$ & 2150 & $22 \%$ \\
\hline \multirow[t]{2}{*}{14} & 3.996 & & & & & & & \\
\hline & & $13 \%$ & 1,010 & 47 & $-11 \%$ & $-14 \%$ & 2350 & $25 \%$ \\
\hline 15 & 9.381 & & & & & & & \\
\hline
\end{tabular}


It can be seen that the price formation for marketing in Table 4 gives an account of prices that could be reduced without sacrificing appropriate profitability. This reduction, then, would be adjusted to the needs of increasing housing accessibility in a context where the structural housing is deficit in Chile. Moreover, the evaluated commune is Santiago Centro, which concentrates great parts of the jobs on a metropolitan level with great availability of public goods and in addition presents important levels of recent development in the matter of urbanism and infrastructure. It also has a growing rental market (Vergara-Perucich and Aguirre, 2019) which pushes the price up.

An adjustment in the price of housing would allow the weight of the mortgage dividend on the average household budget to fall from an average of $35 \%$ to $25 \%$ for the projects evaluated, thus contributing to the development of a healthier household economy. It is also possible that a reduction in prices could reduce rents and thus improve accessibility in households that do not have the possibility of buying or that prefer to lease.

Even so, the problem of the high price of housing in a context of acute structural housing deficit, under a context of price deregulation, will require greater exploration in the area of public policies that tend to improve the competitiveness of housing values, which expands the possibilities of access for middle- and lower-income households to consolidated areas of the city.

\section{Conclusions}

A report by Leilani Farha, UN Special Rapporteur on Housing, comments that the commodification of housing in Chile jeopardises its universal access and that the lack of regulation of the housing market harms homes (Farha, 2018). The problem of access to housing in Chile is related to the optimal profitability of some companies in the industry, as discussed in this article. Given that projects could offer lower housing prices without losing profitability, it is possible to propose that public-private solutions would be an appropriate path. That is to say, the intervention of the state in the formation of prices could be generated from improving the mechanisms of regulation and generating criteria of fixation of prices, without involving the state in the process of building houses. This, in any case, is not something new in the Chilean context.

In the 1920s, for example, there was a social organisation in Chile known as the Liga de Arrendatarios (League of Tenants) that organised itself to not pay the rent for a few months because it considered them unfair and excessive: in many cases a house without windows exceeded $80 \%$ of the worker's monthly income. This social movement led to the implementation of the Decree-Law 261 of 1925, which regulated the price of housing: it reduced the price of those considered unhealthy by the authority by $50 \%$, limited the optimal housing price according to household income and protected tenants from evictions for six months without payment (Espinoza, 1988; Sagredo and Gazmuri, 2007).

Another important historical example occurred in 1967, when President Eduardo Frei Montalva modified the Constitution and, through Law 16.615, established that private property was subordinated to the social role played by land. Through this, progress began towards a planning mechanism to execute projects of high public interest. Among them were diverse works of affordable housing that until today could be seen in consolidated neighborhoods of the city of Santiago, all this with the state as the organising agent of the demand and controller of the processes, where the private company acted as executor without ceasing to receive important profits (Hidalgo-Dattwyler, 2019). To a series of historical examples that were implemented in Chile, explorations are also being 
developed in other nations, from different perspectives, aimed at generating price control mechanisms to ensure universal access to housing.

On the other hand, there is a dynamic at the level of business controllers that could not be unraveled from the study presented here, but that does open up new possibilities for future research. It would be relevant to review the interests of shareholders and controllers that have such an impact when it comes to establishing the expected returns for projects, whether there are indications on construction quality, urban areas to invest or discussions on mechanisms for setting prices when it comes to increasing profits. An investigation into the board minutes of large companies, together with a series of semi-structured or in-depth interviews, could help review another aspect of real estate profitability that is on a company scale and not on the scale of individual projects, as has been the case in this study.

Chile has been part of the drafting nations and has subscribed to the New Urban Agenda, where the problem of affordability of housing and public-private relations to ensure access are among the commitments for the next decade (UN, 2017). Part of these commitments are inscribed in the new National Urban Development Policy (CNDU, 2015), a project that has been under discussion since 2013 but which is progressing timidly. One of its recent advances has been the project to modify the General Law on Urban Planning and Construction, which establishes conditions for densifying strategic areas of cities, a situation that has raised some doubts before an excessive power given to the Minister of Housing and Urbanism, who could decide where to change the urban regulation without being obliged to consult local communities and without binding participatory processes (Bannen, Rojas, Ruiz-tagle, and Vicuña, 2019). Even so, the problem of access to housing in Chile is on the current political agenda and household prices, profitability and ability to pay should not be left out of the discussion.

\section{References}

1. Banco de Central. (2018). Informe de estabilidad financiera Segundo Semestre 2018 (Vol. 46). Santiago.

2. Bannen, P., Rojas, C., Ruiz-tagle, J., \& Vicuña, M. (2019). Observaciones y propuestas al proyecto de ley de integración social y urbana (No. 5). Retrieved from http://estudiosurbanos.uc.cl/images/publicaciones/documentos-de-trabajo/Doc_trabajo_ley_integracion.pdf

3. Cattaneo Pineda, R. A. (2011). Los fondos de inversión inmobiliaria y la producción privada de vivienda en Santiago de Chile: ¿Un nuevo paso hacia la financiarización de la ciudad? EURE (Santiago), 37(112), 5-22. https://doi.org/10.4067/S0250-71612011000300001

4. CNDU. (2015). Política Nacional de Desarrollo Urbano. https://doi.org/http://cndu.gob.cl/wpcontent/uploads/2014/10/L4-Politica-Nacional-Urbana.pdf

5. Contreras, D., \& Ffrench-Davis, R. (2012). Policy Regimes, Inequality, Poverty and Growth: The Chilean Experience, 1973-2010. Unu-Wider. https://doi.org/http://www.wider.unu.edu/stc/repec/pdfs/wp2012/WP2012004.pdf

6. Contreras Gatica, Y. (2011). La recuperación urbana y residencial del centro de Santiago: Nuevos habitantes, cambios socioespaciales significativos. EURE (Santiago), 37(112), 89-113. https://doi.org/10.4067/S0250-71612011000300005

7. Contreras, Y. (2010). SANTIAGO CENTRO: ¿PUEDE CONVIVIR UN ESPACIO RESIDENCIAL CENTRAL CON EL LOCUS DE ESPECULACIÓN INMOBILIARIA? Scripta Nova, XIV(331 (89)), 1-11. Retrieved from https://www.raco.cat/index.php/ScriptaNova/article/view/200449

8. Encinas, F., Aguirre, C., Truffello, R., \& Hidalgo, R. (2019). Speculation, land rent and the neoliberal city. Or why free market is not enough? Revista $A R Q, 1(102), 2-15$. 
9. $\quad$ Espinoza, V. (1988). Para una historia de los pobres en la ciudad. Santiago: Ediciones SUR.

10. Evans, A. W., Sabatini Downey, F., Brain Valenzuela, I., Es, Q. U. E., Economia, L. A., Bergoeing, R., ... Hidalgo, R. (2017). Desarrollo Urbano de Santiago: Perspectivas y Lecciones. Economics, Real Estate and the Supply of Land. https://doi.org/10.1002/9780470698860

11. Farha, L. (2018). Report of the Special Rapporteur on adequate housing as a component of the right to an adequate standard of living, and on the right to non-discrimination in this context, on her mission to Chile. Retrieved from https://documents-dds-ny.un.org/doc/UNDOC/GEN/G18/009/43/PDF/G1800943.pdf?OpenElement

12. Ferson, W. E. (2013). Investment Performance: A Review and Synthesis. In Handbook of the Economics of Finance (pp. 969-1010). https://doi.org/10.1016/B978-0-44-459406-8.00014-7

13. Fundación Vivienda. (2019). MODIFICA LA LEY GENERAL DE URBANISMO Y CONSTRUCCIONES ESTABLECIENDO UNA RESERVA DE SUELO URBANO DESTINADA A VIVIENDAS DE BAJO VALOR. Retrieved from https://www.camara.cl/pdf.aspx?prmID=149271\&prmTIPO=DOCUMENTOCOMISION

14. Garreton, M. (2017a). City profile: Actually existing neoliberalism in Greater Santiago. Cities, 65, 32-50. https://doi.org/10.1016/j.cities.2017.02.005

15. Garreton, M. (2017b). City profile: Actually existing neoliberalism in Greater Santiago. Cities, 65, 32-50. https://doi.org/10.1016/j.cities.2017.02.005

16. Gil-Alana, L. A., Dettoni, R., Costamagna, R., \& Valenzuela, M. (2019). Rational bubbles in the real housing stock market: Empirical evidence from Santiago de Chile. Research in International Business and Finance, 49(November 2018), 269-281. https://doi.org/10.1016/j.ribaf.2019.03.010

17. Ginevičius, R., \& Zubrecovas, V. (2009). Selection of the Optimal Real Estate Investment Project Basing on Multiple Criteria Evaluation Using Stochastic Dimensions. Journal of Business Economics and Management, 10(3), 261-270. https://doi.org/10.3846/1611-1699.2009.10.261-270

18. Goddard, J., \& Marcum, B. (2012). Real Estate Investment:A Value Based Approach. London - New York: Springer-Verlag Berlin Heidelberg.

19. Herbert, C., Hermann, A., \& Mccue, D. (2018). Measuring Housing Affordability: Assessing the 30-Percent of Income Standard. Retrieved from https:/www.housingwire.com/articles/29757-huds-donovan-this-is-theworst-rental-crisis-in-this-

20. Hidalgo-Dattwyler, R. (2019). La vivienda social en Chile y la construcción del espacio urbano en el Santiago del siglo XX. Santiago: RIL Editores.

21. Hidalgo Dattwyler, R., Christian Voltaire, A. P., \& Santana Rivas, D. (2017). La espacialidad neoliberal de la producción de vivienda social en las áreas metropolitanas de Valparaíso y Santiago (1990-2014): ¿hacia la construcción idelógica de un rostro humano? Cad. Metrop., 19(39), 513-535.

22. Hurtado, J. (2019). Gerente de la Cámara Chilena de la Construcción entra al debate por la crisis de la vivienda. Retrieved August 12, 2019, from CIPER Chile website: https://ciperchile.cl/2019/08/09/gerente-de-lacamara-chilena-de-la-construccion-entra-al-debate-por-la-crisis-de-la-vivienda/\#_ftnref1

23. Instituto Nacional de Estadísticas. (2019). Permisos de Edificación. Retrieved August 8, 2019, from Edificación website: https://www.ine.cl/estadisticas/economicas/construccion/edificación-superficie-autorizada

24. Instituto Nacional de Estadísticas (INE). (2018). Censos históricos INE. Retrieved May 2, 2016, from Censos de población y vivienda 1813 - 2002 website: http://www.ine.cl/estadisticas/censos/censos-de-poblaciony-vivienda

25. López-Morales, E. (2016). Gentrification in Santiago, Chile: a property-led process of dispossession and exclusion. Urban Geography, 37(8), 1109-1131. https://doi.org/10.1080/02723638.2016.1149311 
26. Lopez Morales, E., Arriagada Luco, C., \& Gasic Corvalan, D. (2015). Efectos de la renovacion urbana sobre la calidad de vida y perspectivas de relocalizacion residencial de habitantes centrales y pericentrales del Area Metropolitana del Gran Santiago. Eure, 41(124), 45-67. https://doi.org/10.4067/S0250-71612015000400003

27. Manganelli, B. (2015). Real Estate Investing. Retrieved from https://link.springer.com/content/pdf/10.1007\%2F978-3-319-06397-3.pdf

28. Martínez Lemoine, R. (2003). The classical model of the Spanish-American colonial city. The Journal of Architecture, 8(3), 355-368. https://doi.org/10.1080/1360236032000134844

29. MIDESO. (2018). Metodología De Diseño Muestral. Retrieved from http://observatorio.ministeriodesarrollosocial.gob.cl/casenmultidimensional/casen/docs/Diseno_Muestral_Casen_2017_MDS.pdf

30. Miskawi, Z. (1989). An S-curve equation for project control. Construction Management and Economics. https://doi.org/10.1080/01446198900000016

31. ONU. (2017). New Urban Agenda. In Health Visitor. https://doi.org/ISBN: 978-92-1-132757-1

32. Razmilic, S. A. (2010). Property values, housing subsidies and incentives: evidence from Chile 's housing policies by Property values, housing subsidies and incentives: evidence from Chile's housing policies (Massachusetts Institute of Technology). Retrieved from https://dspace.mit.edu/bitstream/handle/1721.1/62112/708579235MIT.pdf?sequence=2\&isAllowed=y

33. Rolnik, R. (2013). Late Neoliberalism: The Financialization of Homeownership and Housing Rights. International Journal of Urban and Regional Research, 37(3), 1058-1066. https://doi.org/10.1111/1468-2427.12062

34. $\quad$ Rolnik, R. (2017). La guerra de los lugares. La colonización de tierra y la vivienda en la era de las finanzas. Santiago: LOM Ediciones.

35. Sagredo, R., \& Gazmuri, C. (2007). Historia de la vida privada en Chile. Santiago: Taurus.

36. Schwartz, M., \& Willson, E. (2006). Who Can Afford to Live in a Home?: A look at data from the 2006 American Community Survey. American Community Survey, (February), 1-13. Retrieved from https://www.census.gov/housing/census/publications/who-can-afford.pdf

37. SECTRA, P. de vialidad y transporte urbano. (2014). Encuesta origen y destino de viajes 2012. 84.

38. Simian, J. M., \& Niklitschek, V. (2017). La Industria Inmobiliaria en Chile. Evolución, desafíos y mejores prácticas. Lima: Pearson - ESE Business School Universidad de Los Andes.

39. Trivelli, P. (2017). Caracterización de zonas con potencial para densificación en comunas pericentrales de Santiago. In T. de I. y Proyecto (Ed.), Densificación con equidad en el anillo pericentral de Santiago (pp. 1-53). Retrieved from http://www.cedeus.cl/wp-content/uploads/2017/05/Pablo-Trivelli-O-compr.pdf

40. Vergara-perucich, F., \& Boano, C. (2018). El precio por el derecho a la ciudad ante el auge de campamentos en Chile . the rise of urban slums in Chile . Revista AUS, 26, 51-57. https://doi.org/10.4206/aus.2019.n26-09

41. Vergara-Perucich, J.-F., \& Aguirre, C. (2019). Investification in Latin America: problematising the letting market in the Chilean case. Habitat y Sociedad, Noviembre(12), 1-20.

42. Vergara, J. E. (2017). VERTICALIZACIÓN. LA EDIFICACIÓN EN ALTURA EN LA REGIÓN METROPOLITANA DE SANTIAGO (1990-2014)*. Revista INVI, 32(90), 9-49. 


\section{Appendix.}

Table of house prices versus remunerations.

\begin{tabular}{|c|c|c|}
\hline Año & $\begin{array}{c}\text { Precio de la } \\
\text { vivienda }\end{array}$ & Remuneraciones \\
\hline jan-10 & 0 & 0 \\
\hline feb-10 & $-0,98177776$ & 0,2706934 \\
\hline mar-10 & $-2,61277639$ & 0,35912158 \\
\hline apr-10 & $-4,77110375$ & 0,86715457 \\
\hline may-10 & $-5,18560762$ & 1,31511806 \\
\hline jun-10 & $-5,95470432$ & 1,47973008 \\
\hline jul-10 & $-3,8576719$ & 1,22747885 \\
\hline aug-10 & $-0,38815118$ & 1,45290787 \\
\hline sept-10 & 1,75271161 & 1,94030792 \\
\hline oct-10 & 1,6631726 & 2,42952977 \\
\hline nov-10 & 2,24360609 & 2,54306315 \\
\hline dec-10 & 4,79204369 & 2,83801455 \\
\hline jan-11 & 6,5796404 & 2,81611612 \\
\hline feb-11 & 7,82473048 & 3,2965402 \\
\hline mar-11 & 7,89022278 & 3,12237545 \\
\hline apr-11 & 9,96835653 & 3,47891547 \\
\hline may-11 & 10,0682464 & 3,28138259 \\
\hline jun-11 & 11,1718748 & 3,75403847 \\
\hline jul-11 & 10,6183154 & 4,11450634 \\
\hline aug-11 & 11,7132932 & 4,20210083 \\
\hline sept-11 & 12,0694969 & 4,56792039 \\
\hline oct-11 & 14,3375216 & 4,55009845 \\
\hline nov-11 & 14,856802 & 4,62956838 \\
\hline dec-11 & 16,3019588 & 4,64000548 \\
\hline jan-12 & 15,2369458 & 5,08090037 \\
\hline feb-12 & 15,7730293 & 5,09811781 \\
\hline mar-12 & 14,5031822 & 5,71993921 \\
\hline apr-12 & 16,1305393 & 5,94247662 \\
\hline may-12 & 15,7966246 & 6,47717179 \\
\hline jun-12 & 14,261383 & 7,06679753 \\
\hline jul-12 & 13,6405982 & 7,77966105 \\
\hline aug-12 & 15,8500916 & 7,97580414 \\
\hline sept-12 & 18,3262406 & 7,815232 \\
\hline oct-12 & 20,6951651 & 7,8202227 \\
\hline nov-12 & 21,1454947 & 8,82560476 \\
\hline dec-12 & 23,6744355 & 9,29604786 \\
\hline jan-13 & 23,4426159 & 9,24686111 \\
\hline
\end{tabular}




\begin{tabular}{|c|c|c|}
\hline feb-13 & 22,582445 & 9,51075721 \\
\hline mar-13 & 21,3316549 & 9,84465826 \\
\hline apr-13 & 23,1948692 & 10,9959967 \\
\hline may-13 & 23,5313517 & 11,3998132 \\
\hline jun-13 & 24,9694819 & 10,8589733 \\
\hline jul-13 & 24,7758033 & 10,6643995 \\
\hline aug-13 & 26,6662853 & 11,3730632 \\
\hline sept-13 & 26,8429885 & 11,5815757 \\
\hline oct-13 & 28,0565491 & 11,7637193 \\
\hline nov-13 & 28,9765504 & 11,7322763 \\
\hline dec-13 & 29,6270801 & 11,678849 \\
\hline jan-14 & 30,2171526 & 11,8910916 \\
\hline feb-14 & 30,9628317 & 12,0296786 \\
\hline mar-14 & 33,8886201 & 11,9675518 \\
\hline apr-14 & 37,8503746 & 12,2413717 \\
\hline may-14 & 39,4341203 & 12,4414638 \\
\hline jun-14 & 40,0766512 & 12,6707 \\
\hline jul-14 & 39,7830483 & 13,1178374 \\
\hline aug-14 & 41,3564011 & 12,9378822 \\
\hline sept-14 & 43,3047546 & 12,8948628 \\
\hline oct-14 & 45,5149861 & 12,5183025 \\
\hline nov-14 & 46,6708313 & 12,9515168 \\
\hline dec-14 & 46,7609047 & 14,036698 \\
\hline jan-15 & 45,8964727 & 14,2987193 \\
\hline feb-15 & 46,3736346 & 14,5634616 \\
\hline mar-15 & 48,260076 & 14,6283005 \\
\hline apr-15 & 50,5462661 & 14,4153153 \\
\hline may-15 & 52,1198348 & 14,5676862 \\
\hline jun-15 & 51,8030986 & 14,5070292 \\
\hline jul-15 & 52,1431362 & 14,6488199 \\
\hline aug-15 & 52,3938522 & 13,8033757 \\
\hline sept-15 & 54,7648913 & 14,104526 \\
\hline oct-15 & 56,0634284 & 14,1608975 \\
\hline nov-15 & 56,7942247 & 14,4882789 \\
\hline dec-15 & 53,9640828 & 14,769849 \\
\hline jan-16 & 53,6788144 & 15,2489455 \\
\hline feb-16 & 53,8373949 & 15,2392768 \\
\hline mar-16 & 59,4052093 & 15,5062656 \\
\hline apr-16 & 58,4137927 & 15,4981246 \\
\hline may-16 & 57,8411883 & 15,5690729 \\
\hline jun-16 & 56,4884046 & 15,7232321 \\
\hline jul-16 & 58,3301614 & 15,5386439 \\
\hline
\end{tabular}




$\begin{array}{ccc}\text { aug-16 } & 58,0916503 & 15,9165129 \\ \text { sept-16 } & 57,2691437 & 15,9524127 \\ \text { oct-16 } & 54,8473943 & 16,3617297 \\ \text { nov-16 } & 54,0161231 & 16,3859282 \\ \text { dec-16 } & 50,8518637 & 16,6764898 \\ \text { jan-17 } & 52,4017644 & 16,759131 \\ \text { feb-17 } & 52,9637645 & 16,6982629 \\ \text { mar-17 } & 58,7593083 & 16,9647571 \\ \text { apr-17 } & 60,405099 & 17,0710235 \\ \text { may-17 } & 61,0781579 & 17,3607988 \\ \text { jun-17 } & 60,1474702 & 18,3171844 \\ \text { jul-17 } & 59,8091815 & 18,709819 \\ \text { aug-17 } & 61,0469525 & 18,881968 \\ \text { sept-17 } & 63,2459956 & 19,155637 \\ \text { oct-17 } & 62,8823517 & 19,2362699 \\ \text { nov-17 } & 61,7653813 & 19,5871821 \\ \text { dec-17 } & 62,0736515 & 19,4191475 \\ \text { jan-18 } & 65,6675056 & 19,3204251 \\ \text { feb-18 } & 68,1067423 & 19,4766406 \\ \text { mar-18 } & 68,1106265 & 19,587536 \\ \text { apr-18 } & 65,6466145 & 20,1560462 \\ \text { may-18 } & 66,4883017 & 20,0087729 \\ \text { jun-18 } & 66,138981 & 20,2411165 \\ \text { jul-18 } & 67,2284521 & 20,0834187 \\ \text { aug-18 } & 67,6453035 & 19,8390988 \\ \text { sept-18 } & 70,9679522 & 20,438279\end{array}$

